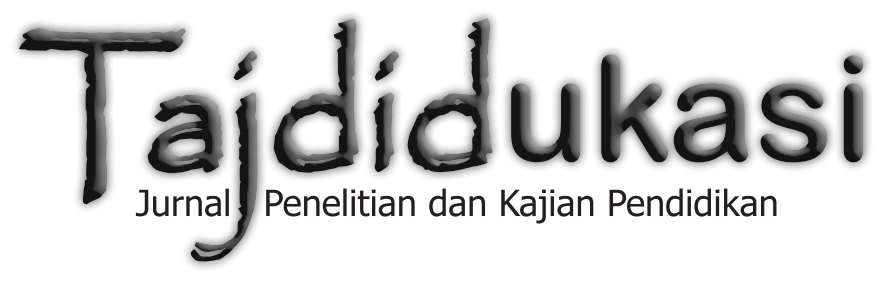




\section{Tajdidukasi}

Volume VIII, No. 1, Januari 2018

ISSN: 1979-6943

Tajdidukasi: Jurnal Penelitian dan Kajian Pendidikan merupakan jurnal Penelitian dan Kajian Pendidikan yang berisi Penelitian Tindakan Kelas (PTK) dan Penelitian Tindakan Sekolah (PTS) serta Kajian Pendidikan interdisipliner di Perguruan Tinggi yang diterbitkan Majelis Pendidikan Dasar dan Menengah Pimpinan Wilayah Muhammadiyah Daerah Istimewa Yogyakarta. Artikel hasil PTK dan PTS serta kajian pemikiran pendidikan ditulis oleh para Guru dan Kepala Sekolah serta Dosen dalam mengujicobakan metode dan strategi pembelajaran untuk meningkatkan kualitas pendidikan baik SD/MI, SMP/MTs dan SMA/MA/SMK serta Perguruan Tinggi. Artikel PTK dan PTS fokus pada mata pelajaran di sekolah/madrasah, seperti Ilmu Pengetahuan Alam (IPA), Imu Pengetahuan Sosial (IPS), Matematika, Fisika, Kimia, bahkan teknik, seperti Teknik Mesin, Elektro, Informatika dan lain sebagainya. Sementara itu, artikel Kajian Pendidikan merupakan penelitian interdisipliner dan multidisipliner yang dilakukan Dosen di Perguruan Tinggi terhadap khasanah keIslaman.

Tajdidukasi: Jurnal Penelitian dan Kajian Pendidikan adalah jurnal terbuka yang versi softfile-nya bisa dibaca dan diakses secara gratis, sementara versi print out/ hardcopy dapat diperoleh dengan menghubungi distributor di alamat serial tajdidukasi.ac.id. Sof-file keseluruhan artikel yang diterbitkan dapat diakses melalui Tajdidukasi Open Access Juornal di www.dikdasmenpwmdiy.or.id

\section{Pimpinan Editor \\ Suyadi, Universitas Ahmad Dahlan (UAD) Yogyakarta, Indonesia}

\section{Anggota Editor}

Arif Budi Raharjo, Universitas Muhammadiyah Yogyakarta (UMY), Indonesia

Achmad Muhammad, UIN Sunan Kalijaga Yogyakarta, Indonesia

Hendro Widodo, Universitas Ahmad Dahlan (UAD) Yogyakarta

Mundzirin Yusuf, UIN Sunan Kalijaga Yogyakarta, Indonesia

Sumedi, UIN Sunan Kalijaga Yogyakarta, Indonesia

Sukamto, Universitas Muhammadiyah Yogyakarta (UMY), Indonesia

Sumarsono, UIN Sunan Kalijaga Yogyakarta Indonesia

Sarjilah (Lembaga Penjaminan Mutu Pendidikan) Yogyakarta

Fathur Rahman, M.Si., Universitas Negeri Yogyakarta (UNY) Indonesia

\section{Editor Pelaksana}

Suryanto, Universitas Muhammadiyah Yogyakarta (UMY), Indonesia

Suyatno, Universitas Ahmad Dahlan (UAD) Yogyakarta

Farid Setiawan, Universitas Ahmad Dahlan (UAD) Yogyakarta

Alamat Redaksi:

Kantor Majelis Pendidikan Dasar dan Menengah Pimpinan

Wilayah Muhammadiyah D.I. Yogyakarta

Jl. Gedongkuning No. 130B Yogyakarta

Kode Pos : 55171

Telephone : (0274) 377078

Facsimile : (0274) 371718

Website : www.dikdasmenpwmdiy.or.id

E-Mail : tajdidukasi@dikdasmenpwmdiy.or.id 


\title{
PENERAPAN HIGHER ORDER THINKING SKILLS (HOTS) UNTUK MENINGKATKAN KETERAMPILAN MEMBACA SISWA SMA
}

\author{
Nailul Author Restu Pamungkas \\ SMA MBS Sleman Yogyakarta \\ e-mail: restupamungkas8@gmail.com
}

\begin{abstract}
Abstrak
Kemajuan teknologi pada abad 21 menuntut siswa agar dapat memiliki kemampuan berpikir kritis dan keterampilan berkomunikasi. Dalam wilayah pendidikan dapat diawali dengan menciptakan proses pembelajaran guna melatih keterampilan berkomunikasi dan berpikir siswa. Tujuan penelitian adalah meningkatkan keterampilan membaca siswa dengan menerapkan pembelajaran bahasa Inggris berbasis HOTS (Higher Order Thinking Skills). Penelitian ini termasuk dalam jenis penelitian tindakan kelas (Classroom Action Research) yang menggunakan desain Kemmis dan McTaggart dengan empat alur (langkah), yaitu (1) perencanaan tindakan; (2) pelaksanaan tindakan; (3) observasi; dan (4) refleksi. Perlakuan dikenakan pada siswa kelas X MIA 2 pada bulan Januari samapai Maret 2018 dengan teknik pengumpulan data menggunakan metode observasi, dokumentasi, catatan lapangan dan tes. Teknik analisis data menggunakan analisis kualitatif interaktif. Hasil penelitian menujukan bahwa penerapan pembelajaran bahasa Inggris yang berbasis HOTS dapat meningkatkan keterampilan membaca siswa. Beberapa siswa mampu mengkritisi sebuah teks dengan pendapat yang logis dan dapat menjawab beberapa pertanyaan yang menuntut kemampuan analisis, evaluasi dan kreasi. Hal itu sejalan dengan nilai rata-rata keterampilan membaca siswa pada kondisi awal sebesar 54,4; meningkat pada Siklus 2 menjadi 60.
\end{abstract}

Kata Kunci: keterampilan membaca, HOTS, Bahasa Inggris.

\section{A. PENDAHULUAN}

Fakta Masyarakat Ekonomi ASEAN (MEA) yang dideklarasikan pada 31 Desember 2015 memunculkan situasi baru dalam perekonomian, perdagangan, teknologi, bisnis dan pendidikan dalam pembatasan pengembangannya. Fakta ini menstimulasi Pemerintah Indonesia dalam mempersiapkan sumber daya manusia yang mumpuni agar dapat ikut serta dalam era pasar global. Bedasarkan hasil laporan dari Mc Kinsey Global Institute (MGI) (2012), pada 2030
Indonesia diprediksikan akan menempati peringkat ke tujuh negara dengan ekonomi termaju. Oleh karena itu, MGI merekomendasikan agar pemerintah Indonesia mempersiapkan SDM yang berkualitas agar mampu menghadapi tuntutan abad 21. Salah satu aspek yang harus dipersiapkan adalah Bahasa Inggris sebagai lingua franca yang digunakan dalam setiap aspek hubungan antar dua negara (Christiansen, 2015).

Pengajaran bahasa Inggris ditingkat SMA sangat penting diupayakan dalam 
menghadapi tuntutan abad 21, karena akan berhadapan dengan pasar global (Reddy, 2016; Gavran, 2013; Hedge, 2008). Penguasaan bahasa Inggris sebagai bahasa asing bagi siswa dalam empat keterampilan membaca, menulis, mendengar dan berbicara mendukung pencapaian kesuksesan dalam era global saat ini. Salah satu aspek keterampilan yang urgen dalam belajar bahasa adalah kemampuan membaca, karena secara tidak langsung dapat meningkatkan kemampuan kosa kata dan kemampuan berbicara (Anderson, 2004).

Penguatan dalam keterampilan membaca, akan berimplikasi pada peningkatan yang signifikan dalam pembelajaran bahasa lainnya (Hermida, 2009; Yee, 2010; Woolley, 2011). Dengan menguasi keterampilan membaca, siswa pembelajar bahasa kedua diharapkan mampu meningkatkan kemampuan mempelajari bahasa Inggris sebagai bahasa asing (Hedge, 2008), memperoleh ilmu pengetahuan yang ditulis dalam bahasa Inggris (McTavish, 2008) serta menjadi modal dasar siswa dalam menangkap informasi di dalam koran, artikel, dan majalah yang berbahasa Inggris (Brown, 2007). Realitas di Indonesia menurut penilaian PISA menempati peringkat 64 (OECD, 2015) dalam kemampuan literasi, matematika dan ilmu pengetahuan siswa di 70 negara di seluruh dunia.

Fakta tersebut sejalan dengan permasalahan yang dihadapi guru di dalam kelas, yakni siswa kesulitan dalam menguasai keterampilan membaca. Bukti hasil Ujian Tengah Semester (UTS) cukup rendah dimana seluruh butir soal menguji kemampuan membaca (Rata-rata nilai UTS siswa MBS kelas X MIP 2 53,4). Dikuatkan data dari Puspendik bahwa nilai Ujian Nasional (UN) Bahasa Inggris dalam kategori rendah dibanding mata pelajaran lain yang mengindikasikan bahwa pembelajaran bahasa Inggris perlu dievaluasi dan mencarikan solusi pembelajaran yang tepat. Salah satu faktor terpenting dalam pembelajaran bahasa Inggris khususnya keterampilan membaca adalah perlunya mengakomodasi Higher Order Thinking Skills (HOTS) dalam setiap langkah (Girgin's 2006; Krathwohl, 2002; Moore \& Stanley, 2010). Proses membaca teks juga dianggap memerlukan kemampuan HOTS untuk dapat memahami, menganalisis, mengevaluasi dan menyimpulkan informasi yang didapat (Aloqaili, 2012). Weimer (2012) berpendapat bahwa HOTS dapat difasilitasi melalui kegiatan membaca. Beberapa penelitian yang terkait juga menemukan bahwa aktifitas yang memancing siswa berfikir kritis dapat meningkatkan keterampilan membaca siswa (McKown \& Barnett, 2007; Acosta \& Ferri, 2010; Yoke, et.all, 2015).

Maka dari itu, sudah semestinya pengajaran bahasa Inggris, khususnya untuk keterampilan membaca, perlu menerapkan HOTS dalam setiap langkah. Hal itu juga harus didukung dengan kompetensi guru yang baik agar mencapai hasil yang maksimal, karena guru merupakan elemen ter- 
penting dalam proses belajar mengajar dikelas. Hal itu sejalan dengan Ashadi dan Rice (2016) yang mengemukakan bahwa kualitas guru pada suatu negara berpengaruh terhadap rata-rata pendapatan suatu negara. Guru harus mampu menghadapi tantangan pengajaran dan pembelajaran yang berbasis HOTS. Namun pada kenyataannya, guru belum mampu menciptakan proses pembelajaran yang berbasis HOTS. Dalam sebuah penelitian yang dilakukan oleh Ivie (1998) menemukan bahwa seringkali HOTS tidak mendapatkan perhatian yang serius dari guru.

Maka dari itu, pengembangan kompetensi guru yang mampu mengakomodasi HOTS perlu dilakukan. Sistem pendidikan yang ideal harus menghasilkan siswa yang mampu berfikir kritis dan mampu memecahkan masalah, yang hingga kini masih menjadi pekerjaan rumah bagi seluruh stakeholder. Pembelajaran bahasa Inggris yang berbasis HOTS harus terus diusahakan, dimulai dari perencanaan hingga implementasi, dimana guru harus berusaha mengembangkan pengajaran yang dapat mengakomodasi HOTS di dalam kelas. Menanggapi fenomena tersebut, penelitian ini bertujuan untuk mengembangkan model pembelajaran bahasa Inggris yang berbasis HOTS untuk meningkatkan keterampilan membaca siswa.

\section{B. METODE PENELITIAN}

Penelitian ini merupakan penelitian tindakan kelas yang mengadopsi desain dari Kemmis dan McTaggart (1992:5) yakni (1) perencanaan tindakan (planning); (2) pelaksanaan tindakan (action); (3) observasi (observing) dan (4) refleksi (reflection). Penelitian ini dilaksanakan dalam 2 siklus, yang mana tiap siklusnya melalui tahapan sebagai berikut:

\section{Perencanaan}

Tahap perencanaan meliputi kegiatan:

a. Menyusun rencana pembelajaran membaca yang berorientasi pada HOTS

b. Menyusun instrumen penelitian seperti lembar observasi, catatan anekdot, dan dokumentasi

c. Menyiapkan bahan ajar yang sesuai

d. Menyiapkan soal guna mengukur atau menilai kemampuan membaca siswa dan

e. Berkolaborasi dengan rekan guru serumpun bahasa Inggris guna mengobservasi dan mencatat proses pemebelajaran

\section{Tindakan}

Dalam tahapan tindakan, guru menerapkan semua rencana yang telah disusun. Tindakan yang dilakukan oleh guru secara garis besar meliputi pendahuluan, kegiatan inti, dan penutup yang hal tersebut akan dilakukan dalam 2 kali pertemuan.

\section{Observasi}

Observasi dilakukan dengan cara mengamati tindakan-tindakan yang dilakukan siswa - baik itu respon po- 
sitif maupun negatif - dan guru selama proses pembelajaran. Selain peneliti yang bertindak sebagai guru sekaligus pengamat, seorang kolaborator juga membantu mengamati dan mencatat aktivitas serta respon siswa selama pembelajaran.

\section{Refleksi}

Tahap akhir dari penelitian ini adalah refleksi, yaitu mengevaluasi proses tindakan dari hasil pembelajaran membaca berbasis HOTS pada siklus 1. Hasil dari refleksi menjadi acuan guna memperbaiki siklus selanjutnya. Hal-hal yang menjadi objek refleksi adalah tes membaca, data dari lembar observasi perilaku siswa selama proses pembelajaran, catatan guru selama proses pembelajaran, kesesuaian bahan ajar dan metode yang digunakan dalam proses pembelajaran, dan hasil catatan dari guru sejawat atau kolaborator yang mengamati proses tindakan yang dilaksanakan. Selanjutnya, hasil dari refleksi siklus satu dievaluasi dan dicari solusi yang nantinya dapat diterapkan pada siklus 2. Dengan kata lain, pada siklus 2 dilakukan perbaikan terhadap permasalahan yang terjadi pada siklus 1 dengan merevisi rencana dan mengantisipasi permasalahan yang terjadi pada saat tindakan.

Penelitian dilaksanakan di SMA Muhammadiyah Boarding School Sleman. Subjek penelitian ini adalah 34 siswa kelas X MIA 2 SMA MBS Yogyakarta tahun ajaran 2017/2018. Kemudian lembar observasi dalam penelitian ini digunakan untuk mengamati proses pembelajaran yang berbasis HOTS guna meningkatkan keterampilan membaca mereka. Aspek yang diamati meliputi keterlaksanaan pembelajaran oleh guru mulai dari kegiatan awal, kegiatan inti, dan kegiatan akhir, serta aktivitas siswa dalam pembelajaran.

Catatan lapangan digunakan untuk mendokumentasikan secara tertulis tanggapan siswa terhadap proses pembelajaran yang terjadi. Tes berbentuk pilihan ganda pada penelitian ini digunakan untuk mengukur kemampuan membaca dalam menganalisis dan mengevaluasi teks bahasa Inggris. Tes ini dilakukan sebanyak dua kali pada siklus pertama dan siklus kedua. Bentuk tes dan kriteria penilaian yang digunakan dalam kedua siklus sama, yaitu dimaksudkan untuk menguji keterampilan membaca siswa. Soal terdiri 20 butir, 5 diantaranya akan menguji kemampuan HOTS siswa, yakni analisis, evaluasi dan mencipta. Untuk dapat dianalisis, data diambil menggunakan instrument yang tepat guna memastikan data tersebut valid dan reliable.

Hasil dari perhitungan tes prasiklus, siklus 1, dan siklus 2 kemudian dibandingkan, agar dapat memberikan gambaran mengenai peningkatan keterampilan membaca dan tingkat keberhasilan penelitian. Data catatan lapangan dianalisis menggunakan teknik analisis kualitatif interaktif yang dikembangkan oleh Miles dan Huberman (1984). Analisis interaktif tersebut terdiri atas tiga komponen kegiatan yang saling terkait 
satu sama lain: reduksi data, tampilan data, dan penarikan kesimpulan.

\section{HASIL DAN PEMBAHASAN \\ 1. Siklus 1}

Terdapat 2 siklus yang dlakukan dalam penelitian ini, masing-masing siklus terdiri dari 2 pertemuan dan meliputi perencanaan, tindakan, observasi dan refleksi. Siklus 1 diawali dengan mengidentifikasi setiap permasalahan yang terjadi di kelas, kemudian merumuskan kedalam beberapa poin dan menentukan solusi permasalahan dengan membuat perencanaan penerapan model pembelajaran bahasa Inggris yang berorientasi pada HOTS yang dituangkan dalam RPP. Prosedur inti dalam penelitian ini adalah penerapan model pemebelajaran bahasa Inggris yang berbasis HOTS.

Pelaksanaan tindakan Siklus 1 terdiri dari dua pertemuan dan dilaksanakan pada tanggal 18 Februari 2018 dengan materi introducing recount text. Pembelajaran dilaksanakan di kelas X MIA 2 dengan jumlah siswa sebanyak 35 orang. Pada kegiatan pendahuluan, guru membuka pelajaran sebelum memberikan motivasi dan menjelaskan mengenai materi pembelajaran yang akan dilaksanakan. Selanjutnya guru menjelaskan tujuan pembelajaran, yaitu agar siswa dapat mengidentifikasi fungsi sosial, struktur teks dan unsur kebahasaan teks recount, menyunting teks lisan dan tulis sederhana teks recount, menyusun teks lisan dan tulis sederhana teks recount lisan dan tulis berbentuk peristiwa bersejarah. Pada bagian akhir kegiatan pendahuluan, guru mulai memberikan apersepsi dengan memberikan pertanyaan kepada siswa tentang definisi dan jenis-jenis teks recount.

Pada kegiatan inti, guru membagi kelas menjadi beberapa kelompok kecil yang beranggotakan dua orang siswa. Selanjutnya guru memberikan masalah yang harus didiskusikan atau didialogkan secara mendalam oleh kelompok tersebut mengenai topik yang terlampir dalam soal diskusi. Setelah siswa selesai berdiskusi, guru membentuk kelompok besar yang beranggotakan 5 orang secara acak dan siswa mengulas kembali permasalahan yang sebelumnya telah didiskusikan pada kelompok kecil. Siswa berdialog dan bersikap terbuka tentang solusi mereka dalam permasalahan tersebut. Setelah diskusi kelompok besar selesai, guru memberikan kesempatan kepada siswa untuk mempresentasikan hasil diskusinya. Siswa pada kelompok lain memperhatikan kelompok yang sedang melakukan presentasi. Setelah kegiatan presentasi selesai, guru memberikan refleksi mengenai proses pembelajaran yang telah dilakukan. Guru membimbing siswa untuk menarik kesimpulan dan poin penting dari materi teks recount. Pada kegiatan penutup, guru memberikan soal tentang materi yang telah dipelajari dan siswa mengerjakan soal tersebut secara individu.

Selama pelaksanaan tindakan guru 
dibantu kolaborator atau rekan sejawat mengobservasi proses pembelajaran dengan mencatat hal-hal penting yang sesuai dengan panduan. Berdasarkan hasil observasi terhadap keterlaksanaan pembelajaran oleh guru pada Siklus 1, ditemukan bahwa pada kegiatan awal guru sudah membuka pelajaran dengan salam, memberikan motivasi dan menjelaskan mengenai model pembelajaran yang akan dilaksanakan kepada siswa, menjelaskan tujuan pembelajaran, dan memberikan apersepsi. Pada kegiatan inti, guru sudah membagi siswa menjadi kelompok kecil yang beranggotakan dua orang siswa. Guru juga sudah memberikan masalah yang harus didiskusikan atau didialogkan secara mendalam oleh kelompok tersebut. Guru sudah memberikan pertanyaan kepada setiap kelompok secara acak. Guru juga sudah membentuk kelompok besar yang beranggotakan 5 siswa secara acak.

Secara keseluruhan proses pembelajaran sudah berlangsung sesuai dengan rencana. Guru juga membimbing siswa untuk menarik kesimpulan dan poin penting dari materi yang telah dibahas bersama. Hal tersebut tentu sangat bermanfaat dalam memancing siswa untuk lebih aktif dan memfokuskan pendapat siswa. Namun ada beberapa hal yang belum terlaksana dengan baik ada siklus ini. Aspek yang belum terlaksana pada siklus 1 adalah guru belum memberikan informasi mengenai manfaat materi teks recount dalam kehidupan seharihari. Guru juga belum memberikan refleksi mengenai proses pembelajaran yang telah dilakukan. Pada kegiatan penutup, guru sudah memberikan soal tentang materi yang telah dipelajari dan menutup pelajaran dengan salam. Selain observasi yang dilakukan kolaborator, guru pun melakukan pengamatan selama proses pembelajaran berlangsung.

Setelah siswa diberikan tindakan melalui pembelajaran yang berorientasi pada HOTS, guru melihat bahwa tindakan yang dilakukan bedampak positif pada siswa. Perhatian dan keaktifan siswa pada siklus pertama ini mengalami sedikit peningkatan dibandingkan sebelum adanya tindakan. Selama proses pembelajaran siswa actif dalam berdiskusi dan mendengarkan penjelasaan guru. Sebelum adanya tindakan, siswa lebih pasif dalam proses pembelajaran dan hanya mengerjakan tugas yang ada di buku paket. Hal ini membuktikan bahwa memberikan suatu permasalahan untuk didiskusikan memebuat siswa lebih tertantang untuk ikut berpartisipasi dlam kebigiatan pembelajaran. Hal tersebut sesuai dengan penelitian yang dilakukan Acosta dan Ferri (2015), dengan memberikan beberapa strategi dan pertanyaan yang memancing berfikir kritis siswa menjadi lebih tertantang dan terlibat aktif dalam proses pembelajaran.

Siswa lebih bersemangat menjawab ketika guru memberikan pertanyaan yang memancing berfikir kreatif mereka dengan diberikan tanggung jawab agar mereka mampu menjelaskan di depan teman-teman dalam kelompok mereka. Seperti menjawab istilah yang 
kurang familiar dan mereka berusaha mencari jawabannya dengan berdiskusi. Sedangkan jika hanya disuruh membaca kemudian mencari kata yang sulit hanya sebagian saja yang menjalankannya. Hal itu disebabkan karena mereka tidak diberi tanggung jawab untuk menjelaskan kepada teman mereka yang lain.

Setelah siswa mencari semua penjelasan mengenai susunan teks dan isi di dalam teks tersebut, siswa mulai menjelaskan kepada kelompok lain dan mereka saling bertukar informasi. Kemudian siswa diberikan tugas individu, yakni menentukan teks recount yang baik kemudian merangkum teks tersebut menggunakan kata-kata sendiri. Mereka juga diberikan kesempatan untuk berdiskusi dengan teman sebangku. Dalam kegiatan ini, siswa terlihat aktif dan antusias dalam bertanya. Selain itu juga siswa diberikan bacaan unutuk dibaca dan dipahami. Siswa mampu membedakan teks recount yang baik dengan menyebutkan kriteria yang sesuai. Memberikan kriteria teks recount yang baik dapat meningkatkan kemampuan evaluasi siswa sesuai dengan yang dikemukakan oleh Moore and Stanley (2010). Siswa membaca dengan aktif dan mereka tidak ragu untuk bertanya jika ada hal yang membingungkan menurut mereka. Diakhir pembelejaran mereka diberikan soal tes untuk mengevaluasi hasil pembelejaran mereka. Tabel hasil prestasi belajar siswa dapat dilihat pada tabel berikut ini.

\section{Tabel 1. Hasil Tes Siswa (Siklus 1)}

\begin{tabular}{|c|c|c|}
\hline No & Scores & Frequency \\
\hline 1. & $86-95$ & 1 \\
\hline 2. & $76-85$ & 2 \\
\hline 3. & $66-75$ & 6 \\
\hline 4. & $56-65$ & 7 \\
\hline 5. & $46-55$ & 5 \\
\hline 6. & $35-45$ & 11 \\
\hline
\end{tabular}

Tindakan pada siklus pertama belum dapat meningkatkan kemampuan membaca siswa, terbukti dari nilai rata-rata siswa yang masih di bawah KKM yakni 54. Namun ada 9 siswa yang sudah diatas KKM hal ini bisa menjadi acuan untuk siklus selanjutnya. Dari hasil nilai rata-rata pada siklus 1 masih lebih baik dibandingkan sebelum dilakukan tindakan. Hal ini dikarenakan pembelajaran berbasis HOTS menuntut siswa untuk membekali diri dengan informasi dan pemahaman yang cukup agar mampu berpartisipasi (Moore \& Stanley, 2010). Dari hasil siklus 1 tersebut guru bersama kolaborator merumuskan beberapa hal yang harus diperbaiki untuk diimplementasikan pada siklus 2.

Beberapa hal yang akan dilakukan pada tahap selanjutnya yakni guru harus lebih menyederhanakan pertanyaan atau instruksi agar siswa lebih mudah memahami dan siswa lebih mudah menjawab. Guru harus lebih disiplin dalam mengakomodasi waktu setiap tahapan pembelajaran. Guru memberikan kesempatan yang lebih banyak kepada siswa untuk aktif melakukan diskusi 
dan berpendapat dengan menunjuk beberapa nama siswa. Selain itu, guru juga harus memastikan semua siswa ikut terlibat aktif dan lebih memperhatikan siswa yang mengantuk agar lebih fokus dengan memberikan pertanyaan dan membimbing siswa tersebut.

\section{Siklus 2}

Berdasarkan hasil refleksi tindakan Siklus I, maka dilakukan revisi pada rancangan tindakan Siklus II. Perbaikan yang dilaksanakan pada siklus II adalah dengan memberi motivasi kepada siswa dan menjelaskan manfaat pembelajaran untuk kehidupan sehari-hari. Selain itu perencanaan juga merevisi RPP unutk siklus II dengan menambahkan beberapa hal seperti pengaturan waktu yang harus lebih relevan dengan proses pembelajaran. Guru lebih memperhatikan pembagian waktu pelaksanaan pembelajaran agar tidak kekurangan waktu seperti pada pelaksanaan pembelajaran Siklus I. Pada tahap pelakasanaan tindakan proses pembelajaran masih sama seperti pada siklus 1- berdiskusi dalam kelompok kecil dan besar tentang beberapa permasalahan terkait materinamun peneliti lebih menyederhanakan pertanyaan-pertanyaan yang diberikan agar seluruh siswa dapat ikut terlibat. Soal yang diberikan masih menuntut siswa untuk berfikir kritis. Diakhir kegiatan guru memberikan kesempatan siswa untuk membuat ringkasan materi yang telah dipelajari menggunakan bahasa dan kalimat mereka sendiri. Kemudian guru memberikan refleksi mengenai proses pembelajaran yang telah dilakukan.

Observasi dalam pelaksanaan tindakan siklus 2 juga dilakukan, baik oleh kolaborator atau guru itu sendiri. Bahan oservasi adalah keterlaksanaan pembelajaran meliputi kegiatan awal, kegiatan inti, dan kegiatan akhir serta kegiatan siswa dalam pembelajaran. Dari hasil observasi guru sejawat, dilaporkan bahwa guru pada kegiatan awal sudah membuka pelajaran sesuai dengan rencana pelaksanaan dan pedoman.

Guru memberikan motivasi dan menjelaskan mengenai model pembelajaran yang akan dilaksanakan kepada siswa, menjelaskan tujuan pembelajaran, dan memberikan apersepsi. Fungsi guru dalam proses pembelajaran snagat penting untuk memberikan motivasi kepada siswa guna mencipatkan iklim positif dan meningkatkan semangat belajar siswa dalam jangka panjang (Vero \& Puka, 2017). Pada kegiatan inti, guru sudah membagi siswa menjadi kelompok kecil yang beranggotakan dua orang siswa. Guru juga sudah memberikan masalah yang harus didiskusikan atau didialogkan secara mendalam oleh kelompok tersebut. Guru sudah memberikan pertanyaan yang berbasis HOTS namun lebih disederhanakan tingkat kesulitannya. Guru juga sudah membentuk kelompok besar yang beranggotakan 5 orrang secara acak. Anggota kelompok kecil tersebut sudah bertukar kelompok dan membentuk kelompok besar yang beranggotakan 4-6 siswa secara acak. Setelah selesai berdiskusi, guru sudah 
memberikan kesempatan kepada siswa untuk mempresentasikan hasil diskusinya. Guru juga sudah menunjuk satu siswa yang ada dalam kelompok serta satu siswa dalam kelompok lain secara acak untuk memberikan dan mengutarakan mengenai informasi tentang materi yang telah didiskusikan dalam kelompoknya. Guru juga membimbing siswa untuk menarik kesimpulan dan poin penting dari materi yang telah dibahas bersama. Kemudian guru memberikan tugas individu untuk menuliskan teks recount dengan topik yang mereka suka berdasarkan hasil diskusi yang telah dilakukan.

Aspek yang belum terlaksana pada siklus 1 , guru belum memberikan refleksi mengenai proses pembelajaran yang telah dilakukan sudah terlaksana pada Siklus II. Kemudian guru juga sudah memberikan manfaat materi tersebut dalam kehidupan sehari-hari. Pada kegiatan penutup, guru sudah memberikan soal tentang materi yang telah dipelajari dan menutup pelajaran dengan salam. Hasil pengamatan terhadap keterlaksanaan pembelajaran oleh guru menunjukkan bahwa guru sudah melaksanakan pembelajaran sesuai dengan tahap-tahap pembelajaran yang berbasis HOTS dikombinasikan dengan teknik cooperative learning.

Hasil observasi yang dilakukan oleh guru selama proses pembelajaran menunjukan bahwa siswa terlihat lebih aktif dibanding pada siklus 1 . Guru melihat bahwa perhatian siswa terhadap materi pembelajaran lebih meningkat, yakni siswa terlibat aktif jika guru memberi pertanyaan yang merangsang mereka untuk berfikir kritis. Siswa mampu menganalisis teks dan menjawab pertanyaan mengenai teks dengan jawaban yang logis. Guru juga memberikan apresiasi jika siswa mau untuk menjawab pertanyaan dan terlibat aktif dalam proses diskusi. Bubic, Krile dan Kuzman (2015) mengungkapakan bahwa penghargaan kepada prestasi belajar siswa dapat meningkatkan efikasi siswa dalam pembelajaran. Hal ini membuktikan bahwa motivasi dapat meningkatkan iklim pendidikan yang harmonis. Proses pembelajaran berjalan dengan baik, karena peneliti juga memberikan media yang menarik seperti multimedia dan video sebagai input proses pemebelajaran.

Ketika guru memberikan materi tentang recount teks pada pertemuan pertama siklus I, siswa menaruh perhatian lebih terhadap proses pembelajaran. Tidak hanya guru yang aktif bertanya namun siswa juga terlibat aktif bertanya baik kepada kelompok lain ataupun guru. Bahkan siswa juga berani membaca dengan keras dan menjawab pertanyaan lebih percaya diri. Hal itu dikarenakan guru selalu memberi motivasi dan memberikan pertanyaan yang berorientasi pada HOTS. Ini berarti siklus 2 berjalan sudah sesuai dengan rencana dan dapat meningkatkan perhatian siswa terhadap materi pembelajaran.

Guru juga memberikan tanggung jawab kepada semua anggota kelom- 
pok untuk terlibat aktif dalam diskusi, karena guru mencatat semua aktifitas siswa. Hal ini membuat siswa lebih bersemangat dalam berdiskusi dengan teman kelompok mereka. Presentasi setiap kelompok berjalan lebih cair karena setiap kelompok harus memberikan pertanyaan dan masukan. Ketika guru membagikan lembar materi, siswa fokus untuk memahami dan memperlajari materi. Perhatian siswa terhadap proses pembelajaran lebih meningkat dibanding pada siklus 1 , karena guru juga mengumumkan kelompok mana yang memiliki tingkat keaktifan tertinggi. Dampak positif dari pemberian apresiasi sangatlah penting guna meningkatkan kepercayaan diri siswa (Bubic, Krile \& Kuzman, 2015). Peningkatakn keaktifan proses pembelajaran pada siklus 2 sejalan dengan hasil peningkatan prsestasi belajara siswa juga.

Berdasarkan hasil observasi yang dilakukan, mayoritas siswa terlihat dapat mengikuti akftifitas pembelajaran lebih baik. Pembelajaran keterampilan membaca pada pelajaran Bahasa Inggris yang lebih berorientasi pada HOTS dapat membuat siswa lebih aktif dalam proses pembelajaran. Setelah dilakuakan tindakan pada siklus 2 ditemukan bahawa keterampilan membaca siswa meningkat dibanding dengan siklus 1. Untuk lebih jelas tabel dibawah ini menampilakan presentase nilai siswa pada siklus 2 .

\section{Tabel 2. Hasil Tes Siswa (Siklus 2)}

\begin{tabular}{|c|c|c|}
\hline No & Scores & Frequency \\
\hline 1. & $86-95$ & 3 \\
\hline 2. & $76-85$ & 5 \\
\hline 3. & $66-75$ & 7 \\
\hline 4. & $56-65$ & 7 \\
\hline 5. & $46-55$ & 7 \\
\hline 6. & $35-45$ & 4 \\
\hline
\end{tabular}

Dari observasi hasil penilaian keterampilan membaca siswa, secara ratarata nilai siswa meningkat yakni sebesar 59 dibandingkan pada siklus I. Peningkatan hasil belajar siswa juga sesuai dengan pengamatan guru selama proses pembelajaran, yakni siswa terlihat aktif dalam proses pembelajaran. Pembelajaran bahasa Inggris yang berorientasi pada kegiatan dan pertanyaan berbasis HOTS dapat meningkatkan kemampuan membaca siswa. Hal itu karena siswa mendapat pertanyaan yang memancing mereka untuk aktif dan mengekploarasi kemampuan berfikir mereka. Ratarata dari hasil uji coba pada siklus 2 mendapat hasil 60 meningkat dari 54.4 pada siklus 1 . Pada siklus 1 terdapat 9 siswa yang memperoleh nilai diatas 65 , sementara pada siklus 2 terdapat 15 siswa yang memperoleh nilai diatas 65. Dengan demikian, penelitian ini sejalan dengan hasil penelitian yang dilakukan oleh McKown dan Barnett (2007), Acosta dan Ferri (2010), Yoke dkk (2015).

Setelah semua proses pada siklus 2 dijalankan - perencanaan, tindakan dan observasi-peneliti mulai merefleksikan 
semua hasil penelitian. Berdasarkan dari hasil refleksi pada siklus 2 ini, peneliti sudah melaksanakan pemebelajaran sesuai dengan tahap-tahap yang telah direncanakan. Selain itu, indikator keberhasilan penelitian ini juga dapat dilihat dari proses pembelajaran yang diamati oleh peneliti sebagai guru, yakni fakta bahwa selama proses pembelajaran siswa cenderung lebih aktif jika dibandingkan sebelum adanya tindakan. Selain itu, kemampuan membaca siswa juga meningkat dilihat dari hasil penilaian membaca mereka yang pada siklus I hanya memperoleh rata-rata nilai 54.4 meningkat menjadi 60 .

Keberhasilan dari penelitian ini juga kerat kaitanya dengan perbaikan proses pembelajaran yang dilakukan. Analisis sebelum, selama dan setelah pembelajaran sangat penting dilakukan guna memetakan kekurangan dan kelebihan tindakan yang dilakukan selama proses pembelajaran. Dari hasil observasi keterlaksanaan pembelejaran dan hasil nilai kemampuan membaca siswa selama proses pembelajaran lebih baik dibandingkan dengan hasil observasi pada siklus 1. Berdasarkan hasil refleksi pada siklus 2, indikator keberhasilan penelitian ini telah tercapai sehingga tindakan kelas dianggap berhasil dan hanya dilaksanakan sampai siklus 2 . Berdasarkan hasil observasi dan refleksi, pembelajaran bahasa Inggris yang lebih berorientasi pada HOTS dapat meningkatkan keterampilan membaca siswa.

\section{Pembahasaan}

Rendahnya penguasaan bahasa Inggris membuat siswa kesulitan dalam memahami teks yang berbahasa Inggris (Ríos \& Valcárcel, 2005). Karenanya, perlu untuk memelihara motivasi siswa dalam belajar sehingga hal tersebut dapat meningkatkan kemampuan membaca mereka (Vero \& Puka, 2017). Berdasarkan pernyataan tersebut peneliti mencoba untuk menciptakan proses pembelajaran membaca yang menarik dan bervariasi. Dengan menerapkan pembelajaran yang berbasis HOTS dan diskusi, diharpakan hal tersebut dapat lebih efektif dalam proses pembelajaran dan secara tidak langsung dapat meningkatkan kemampuan membaca siswa. Maka dari itu, implementasi HOTS dan diskusi diterapkan dalam tindakan pada siklus 1 dan 2 .

Dalam siklus 1 siswa terlihat pasif dan hanya mengerjakan tugas yang nantinya dinilai. Namun setelah dilakukan tindakan pada siklus 1 siswa jauh lebih aktif, terlihat dari partisipasi mereka dalam proses diskusi dan mempresentasikan hasil diskusi mereka. Larson (2000) mengemukakan bahwa pengajaran menggunakan pendekatan diskusi dapat meningkatkan motivasi siswa dalam pembelajaran dan meningkatkan interkasi verbal mereka. Siswa juga terlihat memperhatikan saat guru memberikan penjelasan mengenai materi yang sebelumnya siswa sudah diskusikan. Dalam proses disksui siswa terlibat aktif terlihat dari partisipasi mereka dalam kelompoknya. Hal ini di- 
sebabkan karena instruksi yang berbasis HOTS merupakan bentuk percakapan yang bertujuan untuk mengeluarkan ide, informasi, ataupun pengalaman, sehingga menjadikan siswa berpartisipasi aktif dalam kegiatan kelompoknya (Siregar, 2013). Selain itu dalam disksusi yang berbasis HOTS siswa juga harus mampu memberikan alasan yang logis. Hal ini dapat dilihat dari keaktifan siswa yang mau menjawab pertanyaan yang diberikan kelompok lain ataupun memberikan tanggapan kepada kelompok lain. Hal ini disebabkan karena pertanyaan-pertanyaan tersebut dirancang agar dapat memencing berfikir kritis. Siswa juga dituntut agar mampu untuk menganalisis sebuah masalah, membuat pertimbangan, dan mengambil keputusan secara tepat (Siregar, 2013).

Pembelajaran yang berbasis HOTS dapat meningkatkan kemampuan siswa bersikap dan berpikir terbuka. Hal ini dapat dilihat dari kegiatan siswa mengerjakan tugas yang diberikan guru. Hal ini disebabkan karena langkah-langkah dalam pembelajaran menuntut siswa untuk mengerjakan soal-soal yang diberikan guru. Jika siswa tidak mengerjakan, maka siswa tersebut akan kesulitan mempelajari materi yang dipelajari karena kegiatan pembelajaran bersumber dari hasil diskusi siswa terhadap soal yang diberikan guru (Sudjana, 1997).

Dalam proses pembelajaran yang telah disusun menuntut siswa agar mampu bersikap secara sistimatis dan teratur dengan bagian-bagian dari keseluruhan masalah yang diberikan. Hal ini dapat dilihat dari kegiatan siswa mengikuti proses pembelajaran dari awal sampai akhir dengan melakukan kegiatan sesuai langkah-langkah pembelajaran, yang meliputi diskusi kelompok dan presentasi kelompok. Dalam proses pembelajaran yang dijalankan harus dilakukan secara tahap demi tahap, sehingga siswa melaksanakan pembelajaran tahap demi tahap (Sudjana, 1997). Uraian tersebut menunjukkan bahwa penerapan pembelajaran yang berbasis HOTS dapat meningkatkan kemampuan siswa dalam menganalisis teks guna menjawab soal yang diberikan.

Pada proses pembelajaran siklus 2, guru selalu mengingatkan siswa untuk berusaha menggunakan bahasa Inggris sebisa mungkin. Guru juga memberikan contoh bagaiamana memaparkan ide menggunakan bahasa Inggris. Pada saat guru memberikan materi recount teks pada siklus 2, siswa terlihat antusias dalam memperhatikan setiap instruksi. Siswa diberikan kesempatan untuk membaca sebuah teks dengan keras sehingga guru bersama murid yang lain dapat mengoreksi jika ada pengucapan yang kurang tepat. Siswa juga dituntut untuk mampu memhami teks karena guru telah menyiapkan pertanyaan yang berbasis HOTS. Butuh kerjasama dan kemampuan analsis agar siswa dapat menjawab pertanyaa tersebeut. "can you tell me, what the contribution of B.J. Habibi to Indonesia and How if he does not exist in Indonesia?". Dengan memberikan pertanyaan tersebut siswa dituntut untuk mampu memhami isi teks 
dan juga menganalisis apa yang terjadi jika Habibi tidak ada di Indonesia (Moore \& Stanley, 2010). Pertanyaan tersebut merupakan satu dari beberapa instruksi yang harus didiskusikan oleh siswa.

Pembelajaran bahasa Inggris yang berbasis HOTS meningkatkan interaksi antara siswa dan guru atau siswa dengan siswa (Larson, 2000). Dengan mengawasi, memandu dan memebrikan umapan balik ke semua kelompok, guru dapat mengetahui apa yang siswa harapkan. Guru juga mengetahui bagian mana yang menjadi permaslahan siswa. Sehingga guru bisa langsung memberikan bimbingan dalam satu kelompok yang nantinya mereka dapat membagikan ke kelompok lain. Siswa juga terlihat senang ketika guru memperhatikan mereka dan interkasi proses pembelajaran dapat lebih meningkat.

Dalam proses pembelajaran pada siklus 2 , siswa dilatih untuk mampu menangkap makna dalam sebuah teks recount dengan diawali siswa mempelajari terlebih dahulu materi tentang recount melaluai diskusi yang berorientasi pada HOTS. Sehingga siswa terbiasa untuk menganalisis sebuah teks yang melatih kemampuan berfikir kritis siswa. Nilai siswa setelah tindakan siklus 2 dapat meningkat cukup signifikan yakni ratarata nilai mereka sebesar 60 , dengan jumlah siswa yang diatas 65 mencapai 15 siswa. Selama proses implementasi aktifitas HOTS, siswa juga terlihat lebih aktif dan mampu manjawab pertanyaan yang menguji kemampuan kritis mere- ka. Hal ini membuktikan pembelajaran yang berorientasi pada HOTS efektif dalam meningkatkan keterampilan membaca, karena dalam proses membacas siswa dituntut untuk menganalisis teks dan menggunakan pengetahuan awal mereka dan mengevaluasi suatu teks (Mckown \& Barnett, 2007).

Penerapan pembelajaran yang berbasis HOTS dapat meningkatkan kemampuan membaca siswa kelas $\mathrm{X}$ MIA 2 SMA MBS Sleman. Hal ini dapat dilihat dari peningkatan nilai membaca mereka. Pembelajaran bahasa Inggris yang berbasis HOTS mengacu pada proses pembelajaran yang menuntut siswa untuk mencari alasan dari jawaban yang mereka berikan. Siswa berusaha mencari informasi dengan baik, siswa berusaha tetap relevan dengan ide utama, siswa bersikap dan berpikir terbuka, siswa mengambil posisi ketika ada bukti yang cukup untuk melakukan sesuatu, siswa mencari penjelasan sebanyak mungkin apabila memungkinkan, dan siswa bersikap secara sistimatis dalam berdiskusi. Hasil ini sesuai dengan beberapa penelitian yang dilakuakan McKown dan Barnett (2007), Acosta dan Ferri (2010), Yoke dkk (2015).

Jadi dapat disimpulkan bahawa penerapan pembelajaran bahasa Inggris yang beroerientasi pada instruksiinstruksi HOTS dapat meningkatkan kemampuan siswa dalam menganalisis, mengevaluasi teks sehingga siswa dapat menjawab pertanyaan dari sebuat teks. Dari hasil nilai pada siklus 1 dan 2 terlihat nilai siswa meningkat sehingga 
pembelajaran yang berorientasi pada HOTS efektif dalam meningkatkan keterampilan membaca siswa.

\section{Kesimpulan}

Penerapan pembelajaran Bahasa Inggris yang berbasis HOTS dapat meningkatkan kemampuan siswa X MIA 2 dalam menjawab pertanyaan-pertanyaan dari sebuah teks yang menutut kemampuan menganalisis, mengevaluasi dan mencipta. Hal ini dibuktikan dengan hasil nilai rata-rata pada siklus 1 sebesar 54,4 dan meningkat pada siklus 2 menjadi 60. Peningkatan keterampilan membaca siswa juga dapat dilihat dari kemampuan menyerap informasi dari sebuah teks. Selain itu beberapa siswa mampu mengkritisi sebuah teks dengan pendapat yang logis dan dapat menjawab beberapa pertanyaan yang menuntut kemampuan analisis, evaluasi dan kreasi. Maka dari itu, model pembelajaran bahasa Inggris berbasis HOTS dapat diterapkan oleh guru-guru dengan pertimbangan situasi, kondisi dan karakter siswa yang mirip dengan penelitian yang dilakukan ini. Karena model pembelajaran tersebut terbukti efektif dalam meningkatkan keterampilan membaca siswa pada mata pelajaran bahasa Inggris.

\section{DAFTAR PUSTAKA}

Acosta, L. M. E. \& Ferri, M. M. 2010. Reading Strategies to Develop Higher Thinking Skills for Reading Comprehension. Jurnal Profile, 12,
107-123.

Aloqaili, A. S. 2012. The relationship between reading comprehension and critical thinking: a theoretical study. Journal of King Saud University, 24, 35-41

Anderson, N. J. 2004. Metacognitive Reading Strategy Awareness of ESL and EFL Learners. The CATESOL Journal, 16.1, 11-27.

Ashadi \& Rice, S. 2016. High stakes testing and teacher access to professional opportunities: lessons from Indonesia. Journal of Education Policy, 6, 727-741.

Brown, D. 2007. Teaching by principles: An interactive approach to language pedagogy second edition. California: Longman.

Bubic, A., Krile, K. \& Kuzman, I. 2015. The Importance of achievement goals and attitudes towards education for explaining adolescents' career decision self-efficacy. Faculty of Humanities and Social Sciences.

Christiansen, T. 2015. The rise of English as the global lingua franca: Is the world heading towards greater monolingualism or new forms of plurilingualism?. Journal Lingue e Linguanggi, 15, 129-154.

Gavran, S. 2013. The importance of English language learning and teaching in South Korea. Master theses, Victoria University.

Girgin, U. 2006. Evaluation of Turkish hearing impaired students' reading 
comprehension with the miscue analysis inventory. International journal of special education, 21, 68-84.

Hedge, T. 2008.Teaching and learning in the language classroom. New York: Oxford University Press.

Hermida, J. 2009. The importance of teaching reading skills in first-year university courses. The International Journal of Research and Review, 3, 20-30.

Ivie, S. D. 1998. Ausubel's learning theory: An approach to teaching higher order thinking skills. The High School Journal, 35-42.

Kemmis, S \& Mc Taggart, R. 1992. The Action Research Planner. Australia: Deakin University Press.

Krathwohl, D.R. 2002. A revision of Bloom's Taxonomy: an overview. Theory into practice, 41, 212-218.

Larson, B. E. 2000. Classroom discussion: a method of instruction and a curriculum outcome. Jurnal Teaching and Teacher Education, 16, 661-677.

McKown, B. A. \& Barnett, C. L. 2007. Improving Reading Comprehension Through Higher-Order Thinking Skills. Master Tesis. Saint Xavier University. Chicago.

McTavish, M. 2008. "What were you thinking?": The use of metacognitive strategy during engagement with reading narrative and informational genres. Canadian journal of educa- tion, 31, 405-430.

MGI McKinse. 2012. The archipelago economy: Unleashing Indonesia's Potential. London: McKinsey and Company.

Miles, M.B. \& Huberman. 1984. Complementary methods for research in education change. Washington: ARA.

Moore, B., \& Stanley, T., 2010. Critical thinking \& formative assessments: Increasing the rigor in your classroom. New York: Eye on Education, Inc.

Organization for Economic Co-operation and Development. 2015. PISA 2015 results in focus. Paris: OECD.

Reddy, M.S. 2016. Importance of English language in today's world. International Journal of Academic Research, 3, 179-184.

Siregar, N. 2013. Efektifitas Model Deep Dialoging/Critical Thingking Pada Pembelajaran Komunikasi Yang Efektif.

Sudjana, N. 1997. Proses BelajarMengajar. Jakarta: Rosdakarya.

Vero, E. \& Puka, E. 2017. The importance of motivation in an educational environment. Jurnal Formazione \& Insegnamento, XV, 57-66.

Wimer, M. 2012. Five characteristics of learner-centered teaching. Article, facultyfocus.com.

Woolley, G. 2011. Reading comprehension: Assisting children with lear- 
Ta j d i d u k a s i, Volume VIII, No. 1 Januari 2018

ning difficulties. Springer Science Bussines Media

Yee, N. 2010. Understanding reading comprehension: Multiple and focused strategy interventions for struggling adolescent readers. Master thesis, unpublished. University of Saskatchewan, Saskatchewan, Canada.

Yoke, S.K., Hasan, N. H., Jangga, R. \& Kamal, S. N. M. 2015. Innovating with HOTS for the ESL Reading Class. Jurnal English Language Teaching, 8, 10-17. 